\title{
Two new rare species of Homoranthus (Myrtaceae: Chamelaucieae) from the Northern Tablelands of New South Wales
}

\author{
John T. Hunter
}

\begin{abstract}
Hunter, J.T. (149 Kentucky St, Armidale, NSW 2350, Australia) 1998. Two new rare species of Homoranthus (Myrtaceae: Chamelaucieae) from the Northern Tablelands of New South Wales. Telopea 8(1): 35-40. Two new species of Homoranthus (H. bornhardtiensis J.T.Hunter and H. croftianus J.T.Hunter) from granitic outcrops on the Northern Tablelands of New South Wales are described with assessments of their conservation status and abundance.
\end{abstract}

\section{Introduction}

During the last decade, several species of Homoranthus have been described in New South Wales and Queensland (Byrnes 1981, Craven \& Jones 1991). Many of these species have come from the granitic outcrops that are common on the New England Batholith. With the intensity of flora survey work being carried out in this region a number of new distributional records and a potential new taxon of Homoranthus have also been discovered (Hunter 1997, Hunter \& Bruhl 1997, Clarke et al. 1998). During recent surveys carried out as an assessment of properties offered to the New South Wales National Parks and Wildlife Service two new Homoranthus taxa were discovered growing on granitic outcrops. These are here described.

\section{Key to species}

The key to the species of Homoranthus presented by Craven \& Jones (1991) should be amended as follows.

1. At least some sepal margins laciniate (the divisions $1.5 \mathrm{~mm}$ or more long) or long acuminately bifurcate

2. Flowering branchlets condensed into a corymbose head

3. Hypanthium 2-3 mm long, style 4-7 mm long H. wilhelmii

3. Hypanthium 3.5-4.5 mm long, style 8-10 $\mathrm{mm}$ long H. tropicus

2. Flowering branchlets not condensed into a corymbose head

4. Leaves 3-4.5 mm long (sepals with 6-10 laciniae) H. darwinioides

4. Leaves $2.5-17 \mathrm{~mm}$ long (if less than $6 \mathrm{~mm}$ long then sepals with fewer than 5 laciniae

5. Leaf blade in transverse section sublinear H. porteri

5. Leaf blade in transverse section subquadrate, suborbicular, subobtriangular or subelliptic 
6. Sepals with 6-12 laciniae H. cernuus

6. At least some sepals with 2-5 laciniae

7. Style 15-21 mm long, leaves 4.5-6 mm long, hypanthium 6-8 mm long H. decasetus

7. Style 1.5-10 mm long, leaves 2.5-11 mm long, hypanthium 2-6 mm long

8. Style 6-10 mm long, leaves $7-11 \mathrm{~mm}$ long, hypanthium glabrous, 5-6 mm long H. biflorus

8. Style $1.5-2.5 \mathrm{~mm}$ long, leaves $2.5-8 \mathrm{~mm}$ long, hypanthium with trichomes, 2-4 mm long H. croftianus

1. Sepal margin distally entire or erose to lacerate (if lacerate the divisions less than 0.5 mm long)

9. Leaves papillate H. papillatus

9. Leaves glabrous

10. Leaves 3-5 mm thick (in side view axe-shaped)

11. Sepals 5-6.5 $\mathrm{mm}$ long, style $22-28 \mathrm{~mm}$ long H. zeteticorum

11. Sepals 3-4 mm long, style 15-19 mm long H. thomasii

10. Leaves $0.3-1.5 \mathrm{~mm}$ thick

12. Peduncles $9-16 \mathrm{~mm}$ long H. floydii

12. Peduncles 0.7-3.5 mm long

13. Style $18-25 \mathrm{~mm}$ long H. homoranthoides

13. Style 3.5-11 mm long

14. Sepals with the apex obtuse H. decumbens

14. Sepals with the apex long acuminate

15. Leaf blade in side view incurved linear

16. Sepals less than $3 \mathrm{~mm}$ long

17. Leaves $3.5-7 \mathrm{~mm}$ long, the blade in transverse section suboblong to subquadrate to subobtriangular; sepals 1-1.5 mm long H. melanostictus

17. Leaves 7-22 $\mathrm{mm}$ long, the blade in transverse section suborbicular to subelliptic to suboblong; sepals $1.5-3$ mm long

16. Sepals $3.5-4 \mathrm{~mm}$ long

H. montanus

15. Leaf blade in side view lunate, scimitar-shaped, narrowly obovate, to incurved linear-obovate

18. Hypanthium with multicellular trichomes between costae
19. Ovules 4-6 H. virgatus
19. Ovules 8-10 H. prolixus

18. Hypanthium glabrous 
20. Hypanthium smooth; style 6-9 $\mathrm{mm}$ long .... H. lunatus

20. Hypanthium ruminate; style $3.5-5 \mathrm{~mm}$ long

H. bornhardtiensis

\section{Homoranthus bornhardtiensis J.T.Hunter, sp. nov.}

H. prolixo Craven \& S.R.Jones affinis sed hypanthio ruminato brevique differt.

Holotype: New South Wales: Northern Tablelands: Bald Rock, 'Bornhardtia', adjacent Ironbark Nature Reserve (30²1'58" 15054'27"), J.T. Hunter 5550 E V.H. Hunter, 9 Nov 1997 (NSW). Isotypes: BRI, CANB, NE.

Shrub to $0.3 \mathrm{~m}$ tall, prostrate, spreading to $1 \mathrm{~m}$ diameter. Stems yellow to reddish when young, turning grey-brown. Leaves opposite, decussate, 4.5-9 mm long, 0.6-0.9 mm wide and thick, aromatic; blade incurved or rarely straight, linear to oblanceolate, in transverse section subobtriangular, abaxially flat or concave, pale green to glaucous, reddish to purplish in spring; apex curved, mucronate to apiculate; petiole $0.1-0.5 \mathrm{~mm}$ long. Flowers solitary in leaf axils, 1-4 on undifferentiated branchlets, yellow. Peduncles 0.7-1.4 mm long, crowned between bracteoles; bracteoles caducous, 3.5-4.5 mm long, red-brown. Hypanthium 5-costate, ruminate between the rounded costae on the ovary region, 1.6-2.5 mm long, 1.1-1.7 mm wide. Sepals 1.2-2 mm long, 0.05-0.1 mm wide, apex long and hair-like, the margins entire, gland-dotted at the base. Petals orbicular, $0.7-0.9 \mathrm{~mm}$ long, $0.8-1 \mathrm{~mm}$ wide, the margin entire. Stamens 10; filaments $0.2-0.4 \mathrm{~mm}$ long; anthers 0.2-0.4 mm long; staminodes 20, free, $0.2-0.4 \mathrm{~mm}$ long. Style glabrous, $3.5-5 \mathrm{~mm}$ long; stigma capitate. Ovules 10. Fruit simple, dry indehiscent nut, $2.5-3.5 \mathrm{~mm}$ long, 1.1-1.7 mm wide, caducous after seed set, orange brown. Flowering October to November (Fig. 1c).

Additional specimens examined: New South Wales: Northern Tablelands: Bald Rock, 'Bornhardtia', adjacent Ironbark Nature Reserve, 30²1' 150 54', Hunter 5551, Sheringham, E Davies, 1 July 1997 (NE); North Rock, 'Bornhardtia', adjacent Ironbark Nature Reserve, 30²0' 150 54', J.T. Hunter 5590 \& V.H. Hunter, 2 Feb 1998 (NE).

Notes: this species was first recorded in Ironbark Nature Reserve by Greg Roberts (Ranger, NPWS Armidale) soon after its dedication in 1985 but was considered to be Homoranthus flavescens. As no collections were made at that time Craven \& Jones (1991) were unaware of it during their revision of the genus. This taxon was collected again during an assessment of a property neighbouring Ironbark Nature Reserve that was on offer to the New South Wales National Parks and Wildlife Service. This property has since gone to public sale. This species can be distinguished from the similar $H$. prolixus by the shorter ruminate rather than hairy hypanthium and the prostrate but not spreading habit. $H$. bornhardtiensis does not flower as prolifically as $H$. prolixus. Craven \& Jones (1991) use hairs on styles as a generic character however, no hairs were noted on collections of this taxon. The lack of stylar hairs may have implications for reproductive biology and conservation.

Etymology: a bornhardt is a dome shaped monolith that is bald and steep-sided. 'Bornhardtia' is also the name of the property from which the type specimen was collected.

Distribution: at present this taxon appears to be restricted to a few isolated granitic outcrops within the Ironbark Nature Reserve and neighbouring properties. Despite a survey of the granitic outcrop areas in the region, no further collections of this species have been made. If no further collections are forthcoming, the present distribution of this species is restricted to a six by seven kilometre patch. 

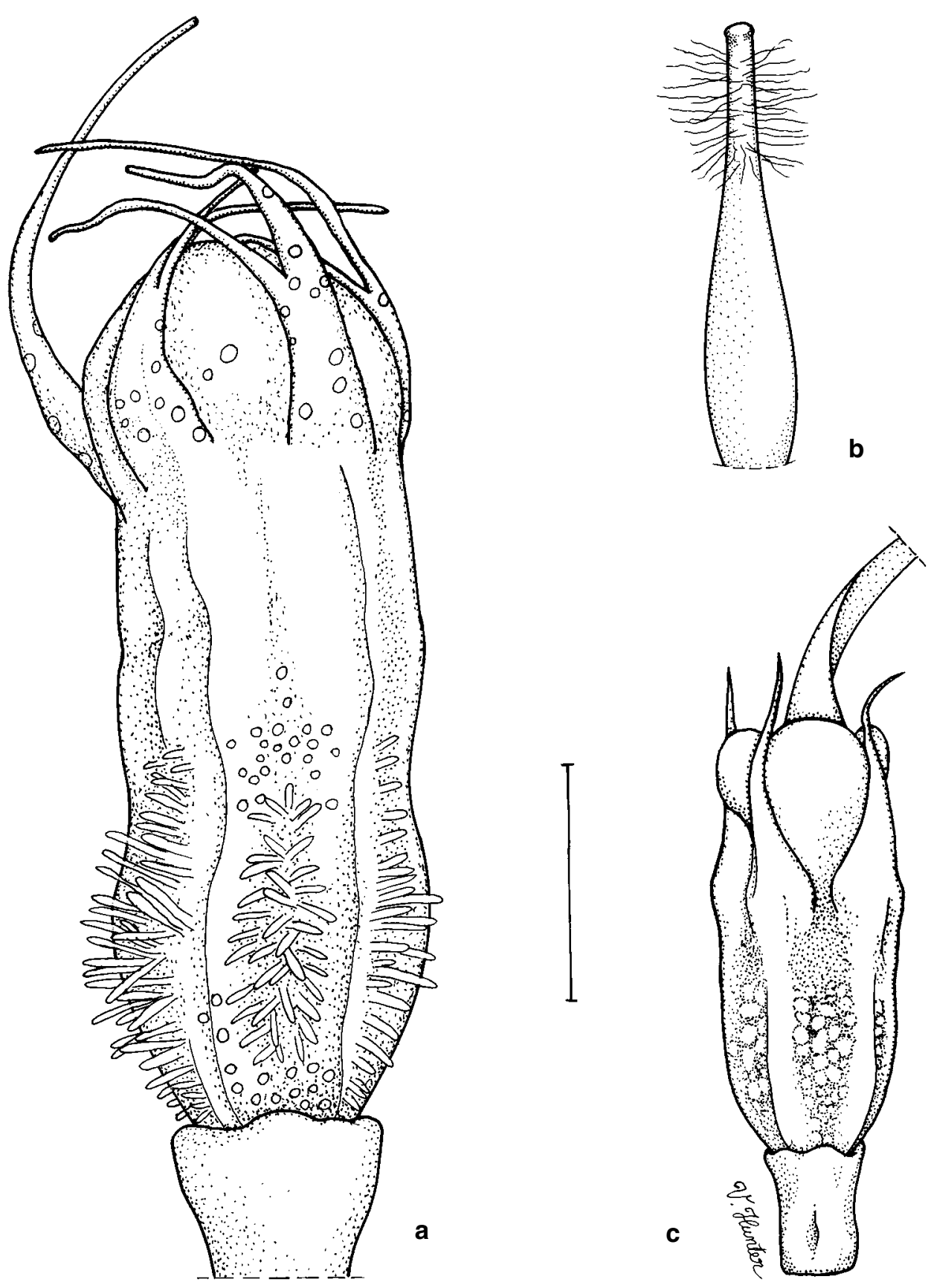

Fig. 1. Homoranthus croftianus. a, unopened flower, note trichomes on hypanthium and 1-3laciniate sepals; b, style with hairy neck. Homoranthus bornhardtiensis. c, flower with bracteoles removed, note undivided sepals and ruminate hypanthium. Scale bar: $a, b=1 \mathrm{~mm} ; c=1.5 \mathrm{~mm}$. Material illustrated is from the types. Illustration courtesy of Vanessa H. Hunter. 
Habitat: found in open and exposed situations in shrubland and low woodland on granitic outcrops between 650-970 m altitude. The annual precipitation at the nearby property 'Granite Heights' is $773 \mathrm{~mm}$. The taxon is found rooted within crevices of bare rocky slopes and in shallow soil surrounding the bare slopes. The $\mathrm{pH}$ of the soils is between 4.5 and 4.75. Associated species include Callitris endlicheri, Eucalyptus prava, E. caleyi, Acacia cheelii, A. neriifolia, Calytrix tetragona, Leucopogon neoanglicus, Ozothamnus obcordatus, Leptospermum novae-angliae, Cryptandra amara var. floribunda, Prostanthera howelliae and Boronia anethifolia.

Conservation status: Homoranthus bornhardtiensis has a very restricted occurrence on only a few disjunct and isolated granitic outcrops within the Ironbark Nature Reserve and surrounding properties. The geographic distribution of this species appears to be only within a $7 \mathrm{~km}$ radius and the population may comprise fewer than 500 individual plants. A preliminary ROTAP code (Briggs \& Leigh 1996) of 2VC is suggested for this taxon.

\section{Homoranthus croftianus J.T.Hunter, sp. nov.}

H. bifloro Craven \& S.R.Jones similis sed hypanthium trichomatibus multicellularibus, sepalis distaliter 1-3-laciniatis differt.

Holotype: New South Wales: Northern Tablelands: Angoperran Hill (29²1' $\left.151^{\circ} 54^{\prime}\right)$, J.T.Hunter 5167, P. Sheringham \& P. Croft, 15 June 1997 (NSW). Isotypes: BRI, CANB, $\mathrm{HO}, \mathrm{MEL}, \mathrm{NE}$.

Erect shrub to $2 \mathrm{~m}$ tall by $1.5 \mathrm{~m}$ wide. Stems yellow to orange when young, turning brown with age. Leaves opposite, decussate, $2.5-8 \mathrm{~mm}$ long, $0.4-0.7 \mathrm{~mm}$ wide, $0.6-0.9 \mathrm{~mm}$ thick; blade incurved or rarely straight or recurved, linear, in transverse section subobtriangular, abaxially flat or concave, dark green to pale green; apex curved or straight, acuminate to cuspidate; petiole $0.1-0.5 \mathrm{~mm}$ long. Flowers solitary in axils on undifferentiated branchlets, greenish to cream. Peduncles $0.7-1.4 \mathrm{~mm}$ long, crowned between bracteoles; bracteoles caducous, gland dotted, $3.5-4.5 \mathrm{~mm}$ long, red-brown. Hypanthium 5-costate, with multicellular trichomes between the rounded costae on the ovary region, $1.5-3 \mathrm{~mm}$ long, 1-1.5 mm wide. Sepals $2-3 \mathrm{~mm}$ long, $0.3-0.6 \mathrm{~mm}$ wide, margins variously divided on individual flowers from undivided to 3-laciniate, glanddotted. Petals orbicular to widely ovate, 1-1.2 mm long, 1-1.4 mm wide, margins entire. Stamens 10; filaments $0.1-0.3 \mathrm{~mm}$ long; anthers $0.3-0.5 \mathrm{~mm}$ long; staminodes 20 , free, $0.3-0.5 \mathrm{~mm}$ long. Style 1.5-2.5 mm long, swollen basally, with long trichomes on the top third; stigma papillate. Fruit simple, dry indehiscent nut, 3.5-4 mm long, $1.2-1.5 \mathrm{~mm}$ wide, caducous after seed set, orange brown. Flowering sporadically June to August (Fig. $1 \mathrm{a}, \mathrm{b})$.

Notes: this species was first discovered during an assessment of a property on offer to the New South Wales National Parks and Wildlife Service. Despite much interest in Bolivia Hill and surrounds by botanists, this species appears to have been overlooked and not collected. The species can be distinguished by its erect habit, distinctive green foliage, long, multicellular trichomes on the hypanthium and variable 1-3-laciniate sepals.

Etymology: named in honour of Peter Croft, a senior ranger at the Glen Innes District National Parks and Wildlife Service. Peter has shown great enthusiasm for understanding the plants and animals around any area he has worked and was present when the type specimen was collected.

Distribution: at present, this taxon is restricted to the Bolivia Range, particularly Angoperran Hill. This species is highly restricted and despite numerous searches of surrounding areas, no further populations have been found. 
Habitat: found in open and exposed situations in shrubland and low woodland on granite outcrops at around $1000 \mathrm{~m}$ altitude. The annual precipitation at Bolivia Hill is around $830 \mathrm{~mm}$. The taxon is found rooted within crevices of bare rocky slopes and in the shallow soil surrounding the bare slopes. The $\mathrm{pH}$ of the soils is between 3.8 and 4.8. Associated species include Callitris endlicheri, Eucalyptus prava, E. dealbata, Leucopogon neoanglicus, Micromyrtus sessilis, Kunzea bracteolata, Boronia anethifolia, Leptospermum novae-angliae, Acacia viscidula, A. pycnostachya and Cryptandra lanosiflora.

Conservation status: Homoranthus croftianus has a very restricted occurrence on large exposed granitic outcrops on and around Bolivia Hill. The geographic range at present is only a few kilometres radius and the population is probably less than 500 individuals. At present the population is not represented in any conservation reserve and a preliminary ROTAP code (Briggs \& Leigh 1996) of $2 \mathrm{~V}$ is suggested for this taxon.

\section{Acknowledgments}

I thank Paul Sheringham, Paul Davies, Peter Croft and Vanessa Hunter for various assistance in the field. Barbara Briggs and Jeremy Bruhl are thanked for allowing access in the past to NSW and NE for examination of Homoranthus specimens. John Williams is thanked for discussion of Homoranthus taxa.

\section{References}

Briggs, J.D. \& Leigh, J.H. (1996) Rare or Threatened Australian Plants, revised edition. (CSIRO: Collingwood).

Byrnes, N.B. (1981) Notes on the genus Homoranthus (Myrtaceae) in Australia. Austrobaileya 1: 372-275.

Craven, L.A. \& Jones, S.R. (1991) A taxonomic review of Homoranthus and two new species of Darwinia (both Myrtaceae, Chamelaucieae). Australian Systematic Botany 4: 513-533.

Clarke, P.J., Copeland, L.M., Hunter, J.T., Nano, C.E., Williams, J.B. \& Wills, K.E. (1998) The Vegetation and Plant Species of Torrington State Recreation Area. (Division of Botany, University of New England: Armidale).

Hunter, J.T. (1997) A further record of Homoranthus lunatus Craven \& S.R.Jones (Myrtaceae) for northern New South Wales. Queensland Naturalist 35: 24-25.

Hunter, J.T. \& Bruhl, J.J. (1997) Significant range extensions for 10 species of vascular plants in northern New South Wales. Austrobaileya 4: 691-694. 